\title{
SUSTAINABLE IRRIGATION WATER MANAGEMENT: CONTEXT OF NATIONAL WATER POLICY
}

\author{
K. Yella Reddy ${ }^{1}$, L. Narayan Reddy ${ }^{2}$ \\ ${ }^{1}$ Director (A\&R) WALAMTARI, Hyderabad. \\ ${ }^{2}$ Director General, WALAMTARI, Hyderabad.
}

\begin{abstract}
The basic dynamics of irrigation development in India are changing. In the past there has been sufficient water and land available to expand the irrigated area. This is no longer the case, with both good quality land and adequate water now constraining further development in many states. Many states are now entering a period of vertical integration, where better management of existing irrigation systems rather than construction of new schemes predominate. This transition will require new skills and expertise within Irrigation Departments if they are to meet the current and upcoming challenges.

As we have stepped into the twenty first century, the new frontier is boosting water productivity, getting more from lesser amount of water devoted to crop production. Improving the performance of completed MMI schemes has been the main focus of the NWM and the 12th FYP and set a target of increasing the WUE by 20\%. WUE studies carried out by the CWC on 30 MMI schemes indicates that in nine schemes WUE was found to be less than 30 percent and the average was 38 percent. The NWM and 12th FYP targets the average figure would need to rise to $46 \%$ by the end of the plan period.

Water measurement and quantification, participatory irrigation management, conjunctive use of surface and ground water, integrated water resource management, modernization of irrigation systems, demand based delivery of irrigation water, large scale promotion of water saving crop production technologies, expansion of micro irrigation into canal command areas are some of the areas identified for sustainable management of irrigation water.
\end{abstract}

Keywords: Sustainable development, Water measurement, Water Use Efficiency, National Water Policy, 12th FYP ****

\section{INTRODUCTION}

Although water is the most widely occurring substance on Earth, only $2.53 \%$ (35 million $\mathrm{km}^{3}$ ) of it is fresh water. The remaining $97.47 \%\left(1,365\right.$ million $\left.\mathrm{km}^{3}\right)$ is salt water. Of the small amount of freshwater, only one third is easily available for human consumption, the large majority being locked up in glaciers and snow cover.

Imbalances between availability and demand, the degradation of groundwater and surface water quality, intersectoral competition, interregional and international conflicts, all bring water issues to the fore. Most countries in the Near East and North Africa suffer from acute water scarcity, as do countries such as Mexico, Pakistan, South Africa, and large parts of China and India. Irrigated agriculture, which represents the bulk of the demand for water in these countries, is also usually the first sector affected by water shortage and increased scarcity, resulting in a decreased capacity to maintain per capita food production while meeting water needs for domestic, industrial and environmental purposes. In order to sustain their needs, these countries need to focus on the efficient use of all water sources (groundwater, surface water and rainfall) and on water allocation strategies that maximize the economic and social returns to limited water resources, and at the same time enhance the water productivity of all sectors.

\section{SUSTAINABLE DEVELOPMENT}

The World Commission on Development (known as Brundtland Commission) in 1987 coined a term 'Sustainable Development' and defined as 'Development that meets the need of the present without compromising the ability of the future generations to meet their own needs'. For example, if sustainable water development is considered, it has been known for more than a century that irrigation without appropriate drainage would result in water-logging and salinity, which would, in turn, progressively reduce agricultural yields over a period of time. Since, main objective of introducing irrigation is to increase agricultural yields, clearly any system that does not fulfill this purpose over the long term cannot be considered sustainable.

Worldwide, after a remarkable period of growth, the pace of irrigation's spread slowed substantially toward the end of the twentieth century. Between 1982 and 1994, global irrigated area grew at an average of 1.3 percent a year, down from an annual rate of 2 percent between 1970 and 1982. Irrigation expansion began to reach diminishing returns. In most of the areas, the best and easiest sites were already developed; bringing irrigation water to new sites was more difficult and costlier.

International Conference on Water and Environment (ICWE) held in Ireland in 1990 indicating the importance of 
water for sustainable development has made the following recommendations (Dublin Principles)

1. Freshwater is a finite vulnerable resource, essential to sustain life, development and environment

2. Water development and management should be based on a participatory approach involving users, planners and policy makers at all levels

3. Women play a central part in the provision, management and safeguarding of water.

4. Water has an economic value in all its competing uses and should be recognized as an economic good.

\section{WATER RESOURCES DEVELOPMENT IN INDIA}

India is endowed with water as a precious natural resource; however, its variability in different regions and over time limits its use for different purposes. Central Water Commission (CWC) has assessed India's surface water potential at 1869 billion cubic meters (BCM), of which 690 BCM is considered utilizable; Central Ground Water Board (CGWB) has assessed additional replenishable groundwater resource as $433 \mathrm{BCM}$. The National Commission on Irrigation and Water Resources Development (NCIWRD) projected both low and high water use requirements for three scenarios of 2010, 2025 and 2050 as given in Table II. 1 and concluded that India would fully utilize its water resources by 2050 .

Table1. Gross water availability and requirements of all water use in India under different scenarios

\begin{tabular}{|c|c|c|c|c|c|c|c|c|}
\hline \multirow{3}{*}{ Source } & \multirow{3}{*}{$\begin{array}{c}\text { Average Annual Utilizable } \\
\text { Water } \\
\text { Availability* } \\
\text { (BCM) }\end{array}$} & \multicolumn{7}{|c|}{ Requirements** $(\mathrm{BCM})$} \\
\hline & & \multirow{2}{*}{$\begin{array}{c}1997 \\
\text { Last Assessed }\end{array}$} & \multicolumn{2}{|c|}{2010} & \multicolumn{2}{|c|}{2025} & \multicolumn{2}{|c|}{2050} \\
\hline & & & Low & High & Low & High & Low & High \\
\hline Surface Water & 690 & 399 & 447 & 456 & 497 & 545 & 641 & 752 \\
\hline Ground Water & 433 & 230 & 247 & 252 & 287 & 298 & 332 & 428 \\
\hline Total & 1123 & 629 & 694 & 710 & 784 & 843 & 973 & 1180 \\
\hline \multicolumn{2}{|c|}{ Return Flows (SW+GW) } & 96 & 116 & 110 & 107 & 125 & 123 & 169 \\
\hline \multicolumn{2}{|c|}{ Unutilized Surface Water } & 334 & 295 & 284 & 263 & 219 & 140 & 42 \\
\hline \multicolumn{2}{|c|}{ Unutilized Ground Water } & 219 & 203 & 202 & 146 & 149 & 96 & 33 \\
\hline \multicolumn{2}{|c|}{ Unutilized Total } & 553 & 498 & 486 & 409 & 368 & 236 & 75 \\
\hline
\end{tabular}

Source: * $C W C \& C G W B ; * *-N C I W R D$

Studies by the International Water Management Institute (Amarasinghe et al, 2007) found that as a result of rising water demand many river basins will be physically water scarce by 2050. According to Amarasinghe of the 19 river basins in India, 8 already have a potentially utilizable water resource of less than $1,000 \mathrm{~m}^{3} /$ capita, with a further 7 currently with less than $1,500 \mathrm{~m}^{3} / \mathrm{ha}$. Only the Narmada $\left(2,448 \mathrm{~m}^{3} /\right.$ capita $)$ and the Mahanadi $\left(2,341 \mathrm{~m}^{3} /\right.$ capita) river basins have adequate water resources available into the foreseeable future. By 205010 river basins, with 75 percent of the total population, will have developed all of the potentially utilizable water resources with the consequence that water reallocation between sectors will be a necessary and common occurrence in these basins. It is predicted that in many basins groundwater, with the current levels of recharge and groundwater use patterns, will be in severe crisis; some already are at catchment and sub-basin level.

Currently over 80 percent of the available water is used by the irrigation sector. In some states, such as Punjab, Rajasthan and Uttar Pradesh, the development of irrigation has resulted in the full development of the water resource, leading to critical water scarcity and shortages of water for other uses. As highlighted in the $12^{\text {th }}$ Five Year Plan, where a large proportion of the ultimate irrigation potential has been realised the focus needs to change from construction of new schemes to more efficient and productive management of already constructed schemes.

Improving service delivery becomes important in the context of the National Irrigation Management Fund (NIMF), established under the $12^{\text {th }}$ FYP. By improving service delivery (which will include measures to improve participation by water users in scheme MOM) the level of water charges collected can be increased, leading to an increase in the funds available to the ID from central government for improvements in the management, operation and maintenance of I\&D systems.

The relative quantities of water being lost at the different levels need to be looked at carefully. The largest volume of water being lost is usually at the field level where the wetted surface area is high and percolation below the root zone is also high. This is particularly the case where rice is grown with ponded water. The next largest volume of water lost is at the on-farm level, where water is distributed field-to-field or through field channels. The management losses are high 
at this level, as are the seepage losses as the ratio of discharge to wetted perimeter is low. Relative to these losses the seepage losses in the main canal network are relatively small, but the management losses can be high if the irrigation scheduling or the level of control and management is poor.

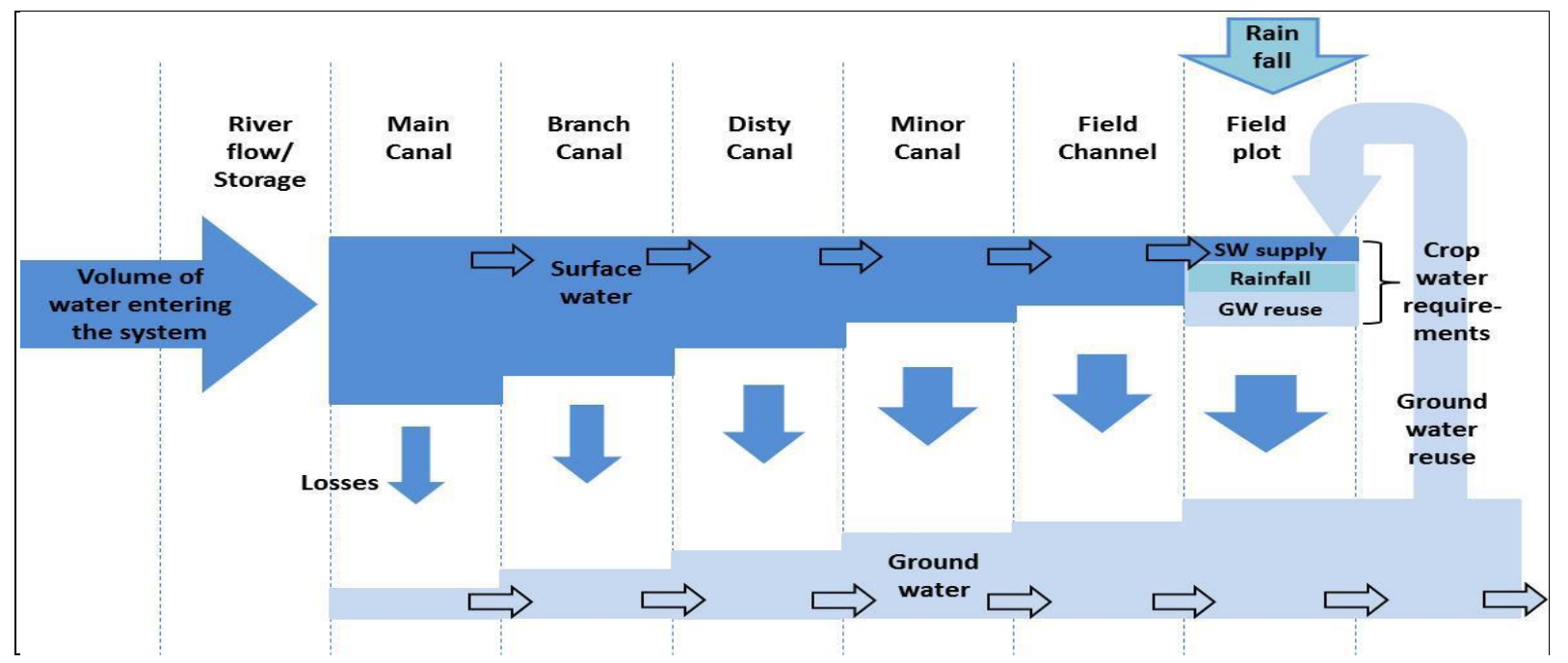

Fig.1. Linkage between different water sources in an irrigation system

Additional area where significant water savings can be made is in active management of rainwater, either by rainwater harvesting on field plots or by allowing for rainfall events in scheduling of irrigation water supplies. Rainwater harvesting can be particularly relevant where paddy is being grown, increasing bund heights to retain larger portions of rainfall events during Kharif can make a significant contribution to conserving water in reservoir-fed systems, leaving more water available for a subsequent Rabi crop.

\section{BENCHMARKING}

Benchmarking can be defined as "A systematic process for securing continual improvement through comparison with relevant and achievable internal or external norms and standards" (Malano and Burton, 2001). Benchmarking can be used to compare the performance of one irrigation schemes with another. By identifying best practice irrigation schemes which form the benchmark for other schemes senior irrigation managers have a valuable tools for raising the performance of all schemes.

A number of benchmarking activities have been carried out since the concept was promoted in the irrigation and drainage sector in the late 1990s/early 2000s (ANCID, 2000; Malano and Burton, 2001; Malano et al; 2004). The ICID formed a Task Force to develop the concept, with early contributions from India and institutionalising of the process in Maharashtra (GoM, 2008). The Indian chapter of INPIM has suggested indicators for benchmarking and the World Bank is currently supporting the development of a web site for benchmarking the performance of Water Users' Associations (http://wua-india.org/about.html).

Benchmarking relies on identifying the key processes which transform the inputs into the desired outputs and impacts (Figure 2).

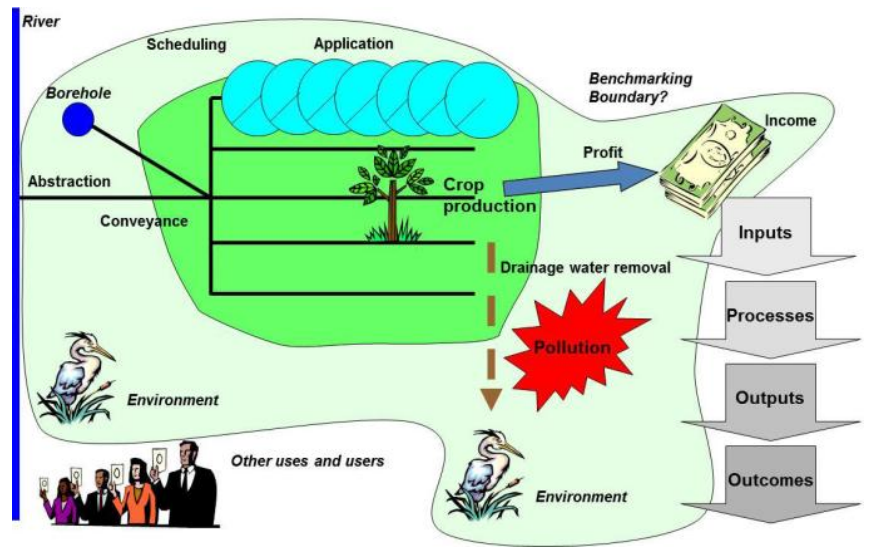

Fig. 2. Identification of key processes in an irrigation and drainage scheme

The objective a CAD\&WM project is to bridge the gap between irrigation potential creation (at canal outlet) and its utilization (in the farmer's fields) through systematically improved land, water and crop management for sustainable optimum agricultural production \& productivity of irrigated commands of major and medium irrigation projects and to improve socio-economic condition of the farmers though integration of various activities related to irrigated agriculture. Organized scientific planning and development of each outlet command is envisaged under the programme through systematic topographical and soil surveys, adopting soil \& climate reliant cropping patterns, consolidating land holdings for economical farming practices; levelling and shaping each farm to suit crops grown and easing extension services; linking each farm with canal outlet through field channels; streamlining farm inputs such as seeds, fertilizers, 
pesticides etc.; provide research and extension services to support advanced high yielding agriculture with due emphasis in providing drains and roads to each farm, market, storage and other infrastructure. The approach adopted at inception of the programme was integrated management of on-farm practices assuming that sufficient water would be available for the designed cropping patterns at the farm outlet. Coordinated efforts of all multidisciplinary departments were planned in an integrated manner to ensure equitable and efficient delivery of water under irrigation Acts. All Irrigation Acts provide recording of water requirements and deliveries at each control and outlet.

\section{PERFORMANCE OF MMI SCHEMES}

The CWC carried out WUE studies for 30 MMI schemes which were analysed and reviewed by the DSDAP team. Improving the performance of completed MMI schemes has been the main focus of the NWM and the $12^{\text {th }}$ FYP and set a target of increasing the WUE by $20 \%$. The $12^{\text {th }}$ FYP quotes figures from WUE studies carried out by the CWC on 30 MMI schemes in which the WUE on nine schemes was found to be less than 30 percent and the average 38 percent. With the NWM and $12^{\text {th }}$ FYP target the average figure would need to rise to $46 \%$. The assessment concluded that:

i) Nearly all the schemes are integrated in nature, with functions other that for irrigation;

ii) The current hydrological pattern of supply to the schemes varies from the original design conditions;

iii) There are concerns over dam safety due to lack of adequate maintenance;

iv) Excessive siltation of reservoirs has reduced their capacity and ability to supply the required volumes of water;

v) Many of the medium and low storage volume reservoirs have a large surface area relative to their depth, resulting in high seepage and evaporation losses;

vi) In many cases the irrigation system is not able to supply the intended demands. This is due to a number of reasons, including non-availability of flows, inadequate capacity at the headworks, excessive losses (including unauthorized abstractions), inadequate capacity of canals, inadequate operating practices;

vii) In many cases there are problems with cross drainage - either due to the inadequate provision of cross-drainage infrastructure, or damaged or broken infrastructure; viii) Control and regulation of irrigation flows is hampered by a lack of functioning control structures, including cross and head regulators;

ix) Discharge measurement is limited;

$\mathrm{x}$ Implementation of participatory irrigation management is often limited or non-existent;

xi) Rotation of water supplies or Warabandi is mainly limited to Punjab and Haryana, though Andhra Pradesh is re-introducing such practices;

xii) Actual cropping patterns vary from the design cropping patterns, resulting in a number of issues. These include head-enders growing more water intensive crops (than designed) resulting in inadequate availability at the tailends of schemes, and irrigation schedules based on design cropping patterns which fail to match actual needs;

xiii) Irrigation from groundwater, ponds and tanks co-exists with the surface water irrigation system, and forms an important part of the farmers decision-making on which crops to grow;

xiv) In some cases where water scarcity exists scheme authorities have proposed diversification away from paddy to irrigated dry crops without assessing the impact on farmers' livelihood;

As a result of analysis of these case studies, and other reports the DSDAP study concluded that there were six core areas requiring priority attention (Table 2) for improving water use efficiency. These were:

Table 2. Core areas wise priority attention

\begin{tabular}{|l|l|}
\hline Core area & Required action \\
\hline Storage & $\begin{array}{l}\text { Consistent and continuous } \\
\text { efforts are required to } \\
\text { improve the performance of } \\
\text { storage facilities order to } \\
\text { enhance the availability of } \\
\text { supplies to the irrigation } \\
\text { schemes. }\end{array}$ \\
\hline Conveyance & $\begin{array}{l}\text { Improvements are required in } \\
\text { the design and the } \\
\text { management of the } \\
\text { conveyance systems }\end{array}$ \\
\hline On-farm application & $\begin{array}{l}\text { On-farm and field irrigation } \\
\text { practices need to be } \\
\text { improved in order to increase } \\
\text { crop production and water } \\
\text { use efficiency }\end{array}$ \\
\hline
\end{tabular}




\begin{tabular}{|l|l|}
\hline Participatory efforts & $\begin{array}{l}\text { Beneficiaries need to play an } \\
\text { increasing role in the } \\
\text { management of the I\&D } \\
\text { systems }\end{array}$ \\
\hline Crop management & $\begin{array}{l}\text { A variety of actions are } \\
\text { required to improve WUE, } \\
\text { including crop } \\
\text { diversification, low water use } \\
\text { crops, better farm } \\
\text { management, micro- } \\
\text { irrigation systems and } \\
\text { provision of quality inputs }\end{array}$ \\
\hline $\begin{array}{l}\text { Research and development } \\
\text { (R\&D) }\end{array}$ & $\begin{array}{l}\text { Further R\&D is required into } \\
\text { water auditing, scheme } \\
\text { monitoring and evaluation } \\
\text { and benchmarking }\end{array}$ \\
\hline
\end{tabular}

In the CWC summary report (CWC, 2010) the results of the studies for each scheme are summarised and an overall summary provided of the common reasons for low water use efficiency and common recommendations for improvement (Table 3).

Table 3. Common reasons and recommendations for low WUE from studies of 30birrigation systems (CWC, 2010)

\begin{tabular}{|l|l|}
\hline $\begin{array}{l}\text { Common reasons for } \\
\text { low WUE }\end{array}$ & $\begin{array}{l}\text { Common recommendations } \\
\text { for improvement of WUE }\end{array}$ \\
\hline $\begin{array}{l}\text { Damaged structures } \\
\text { system in the canal }\end{array}$ & $\begin{array}{l}\text { Rehabilitation and restoration } \\
\text { of damaged/silted canal system } \\
\text { Poor maintenance } \\
\text { Weed growth in the canal and timely maintenance } \\
\text { of the system Selective lining } \\
\text { of the canal and distribution } \\
\text { system } \\
\text { Oveepage in the system } \\
\text { Illiterate farmers } \\
\text { Changing the cropping } \\
\text { pattern }\end{array}$ \\
$\begin{array}{l}\text { Realistic and scientific system } \\
\text { operation } \\
\text { Revision of cropping pattern, if } \\
\text { needed } \\
\text { Restoration/provision } \\
\text { appropriate control structures } \\
\text { Efficient and } \\
\text { communication system } \\
\text { Reliable and accurate water } \\
\text { measuring system } \\
\text { Conjunctive use of ground and } \\
\text { surface water } \\
\text { Regular revision of water rate } \\
\text { Encouragement for formation } \\
\text { of Water Users' Association } \\
\text { Training to farmers } \\
\text { Micro-credit facilities } \\
\text { Agricultural extension services } \\
\text { Encouragement to farmers for } \\
\text { raising livestock }\end{array}$ \\
\hline
\end{tabular}

Table 4. Broad constraints to the implementation of WUE improvement solutions

\begin{tabular}{|c|c|}
\hline Constraint & Explanation \\
\hline Political & $\begin{array}{l}\text { Politics and the I\&D sector are closely } \\
\text { intertwined. Political vested interests } \\
\text { can be a significant constraint on } \\
\text { attempts to modernise the ID or to } \\
\text { improve the efficiency and equity of } \\
\text { water allocation and distribution. }\end{array}$ \\
\hline $\begin{array}{l}\text { Institutional } \\
\text { (including legal) }\end{array}$ & $\begin{array}{l}\text { Many states have outdated Irrigation } \\
\text { and Drainage Acts, only one state, } \\
\text { Gujarat, has enacted a separate Water } \\
\text { Resources Act. The Irrigation } \\
\text { Department's focus on construction of } \\
\text { new schemes is not appropriate in } \\
\text { states where the ultimate }\end{array}$ \\
\hline Organisational & $\begin{array}{l}\text { The Irrigation Department was } \\
\text { established to plan, design, construct, } \\
\text { operate and maintain I\&D schemes. } \\
\text { Due to the pressure to create new } \\
\text { irrigation areas to support a growing } \\
\text { population the focus has been on } \\
\text { planning, design and construction, not } \\
\text { management. The ID is not currently } \\
\text { equipped with the right cadres of staff, } \\
\text { modern skills and expertise required to } \\
\text { efficiently and effectively manage } \\
\text { I\&D systems. }\end{array}$ \\
\hline Technical & $\begin{array}{l}\text { Again, in the government sector, the } \\
\text { focus has been on construction of new } \\
\text { schemes, rather than better } \\
\text { management of existing schemes. } \\
\text { There is not the knowledge and } \\
\text { understanding within the ID which } \\
\text { enables it to modernize its processes } \\
\text { and procedures for efficient } \\
\text { management, operation and } \\
\text { maintenance of I\&D systems. }\end{array}$ \\
\hline Financial & $\begin{array}{l}\text { Finance will be a constraint as long as } \\
\text { adequate funds are not provided to } \\
\text { sustain the built infrastructure. Lack of } \\
\text { adequate finance for sustainable MOM } \\
\text { of I\&D schemes is a major constraint } \\
\text { to adequate levels of service provision } \\
\text { and scheme performance. }\end{array}$ \\
\hline Economic & $\begin{array}{l}\text { Small landholdings and subsistence } \\
\text { cropping result in many farmers living } \\
\text { in poverty. Their economic condition } \\
\text { influences their options and decision- } \\
\text { making, which may sometimes be } \\
\text { optimal for them but sub-optimal for } \\
\text { the scheme. Payment of even small } \\
\text { sums for the ISF is an issue for many } \\
\text { smallholders and/or tenant farmers } \\
\text { who lack financial resources. }\end{array}$ \\
\hline Social & $\begin{array}{l}\text { The large number of smallholder } \\
\text { farmers on I\&D schemes makes it } \\
\text { difficult to implement some measures } \\
\text { (such as laser landlevelling) and to } \\
\text { change on-farm practices. }\end{array}$ \\
\hline
\end{tabular}


Framework for NWUEI support programme assumes vulnerable constrains to be taken up on priority. The guidelines on modernization (ERM) of projects thus requires identification of deficiencies in existing irrigation systems considering suggested mechanism or tools to identify the deficiencies and considering the available options to the reforms. Vulnerable constrains to be taken up on priority. Present guidelines consider extension, restoration/renovation and modernization of the project in one go, which may not be a cost effective solution. Fiscal constraints limit this objective.

Measures to achieve the target of increasing WUE by $20 \%$ are set out in the NWM Comprehensive Mission Document (CMD) and the $12^{\text {th }}$ FYP. The measures proposed include an integrated mix of reform of the Irrigation Department (ID), physical works, improved maintenance, improved management information systems, conjunctive use of surface and groundwater and greater participation by water users in the management, operation and maintenance (MOM) of I\&D schemes. In order to incentivize IDs to reform and address service delivery and maintenance issues the $12^{\text {th }}$ FYP has introduced the National Irrigation Management Fund (NIMF) which provides funds from central government to states in a 1:1 proportion to the water charges collected, with additional funding where these funds are collected by Water Users Associations (WUAs) and a rebate given to the WUAs. Further funds will be provided where water allocation is made by volumetric measurement.

\section{NATIONAL WATER POLICY (2012)}

India recognizes water as a scarce national resource fundamental to life, livelihood, food security and sustainable development. Recognizing that the availability of utilizable water under further constraints is leading to competition among different users, there is a growing concern on spreading scarcity due to its life sustaining characteristics and its economic value, mismanagement, poor governance, minimum ecological needs, inefficient use and rising pollution. The National water Policy (NWP) thus takes cognizance of the situation and has sketched a framework of creation of a system of laws and institutions and has drawn a plan of action considering water as a unified resource.

\section{a) Priority on use of water}

NWP recognized the need for different use and suggests optimized utilisations for diverse use for which awareness on water as a scarce resource should be fostered. Governance institutions must ensure access to a minimum quantity of potable water for essential health and hygiene to all its citizens at their household. Ecological needs should be determined through scientific studies and a portion of water in rivers should be kept aside to meet ecological requirements. Regulated use of ground water should also consider contribution of base-flow to the river during lean seasons through regulated ground water use.

\section{b) NWP on impact of climate change}

NWP recognizes the importance of adaptation to the impacts of climate change by the community through resilient technologies and endorses adaptation to strategies on increasing storages, demand management, stake holder's participation, and paradigm shift in design of river valley projects in coping with strategies to mitigate the impacts of climate change.

\section{c) Enhancing water availability for different use}

The availability of water should be periodically and scientifically reviewed and reassessed in various basins every five years considering changing trends in climate change and accounted for in the planning process. Integrated watershed development activities with groundwater perspectives need be adopted to enhance soil moisture, reduce sediment yield, and increase overall land use productivity of rural development schemes.

\section{d) Demand management}

The policy recommends evolution of a system of benchmarks for water uses for different uses, water footprints, and water auditing to promote and incentivize efficient use of water with clear emphasis on improving 'project' and 'basin' water use efficiencies through appropriate water balance and water accounting studies. Institutional arrangements for promotion, regulation and evolving mechanisms for efficient use of water at basin/subbasin level need be established.

Project appraisal and environmental impact assessment for water uses to inter-alia include:

(i) analysis of water foot prints,

(ii) recycle and reuse including return flows to be a general norm,

(iii) incentivizing economic use of water to facilitate competition,

(iv) adaptation to water saving means in agriculture such as controlled cropping patterns in endowment with climate, micro irrigation, recycling canal seepage through planned conjunctive use,

(v) monitoring a performance and

(vi) reclamation of commands from water logging, salinity and alkalinity.

\section{e) Regulation of water prices}

A water regulatory authority should be established in each state to fix and periodically review and regulate the water tariff system and charges according to the principles of NWP. Volumetric assessment and allocation, entitlement and distribution should be the criteria to ensure equity, efficiency and economic principles. WUAs need be given statutory powers to collect and retain a portion of water charges and reuse of recycled water should be incentivized.

\section{f) Project planning \& implementation}

The policy document recognizes the need for planning the water resources projects as per efficiency benchmarks to address the challenge of impeding climate change factors. The projects should incorporate social and environmental aspects in addition to the techno-economic aspects through consultative processes with governments, local bodies, project affected people, beneficiaries and stakeholders. 
g)

Data base and information needs

The policy stresses the need for establishing a 'national water informatics centre' to collect, collate and process all hydrologic and water related information and maintain all information in an open and transparent manner on a GIS platform.

h) Capacity building, research and training needs

The NWP emphasizes on the need for continuous research and advancement of technology, implementing newer research findings, importance of water balance in spatial and temporal context, water auditing for projects and hydrological systems, bench marking and performance evaluation. Need for regular training of the manpower for skill in water management is also recognized.

The provisions of the new NWP are clearly endorsing the principles of IWRM and suggesting that the framework for water planning, development and management should be clearly governed by these principles.

\section{CONCLUSIONS AND RECOMMENDATIONS}

There are wide ranges of issues constraining the performance of MMI schemes throughout the water supply chain from the watershed to the crop root zone. These issues cover several domains - technical, social, economic, legal, political and environmental - with solutions to specific issues requiring action in a mix of these domains.

Better management lies at the heart of any endeavours to improve the situation. Hitherto the government and the Irrigation Department have focused on the construction of new irrigation systems to increase much needed agricultural production and livelihood security for the rural community. With increasing pressure on available water supplies, as emphasised in the $12^{\text {th }} \mathrm{FYP}$, there is a need to focus on better management of constructed irrigation and drainage schemes, making them more efficient and productive, particularly in relation to their water use.

Good management requires good information based on reliable and accurate data - the $12^{\text {th }}$ FYP has highlighted the need for improved data collection, processing and analysis. These data need to be used by management to understand the performance of irrigation and drainage schemes and to improve such performance where it is found to be inadequate, with benchmarking being used to identify gaps between best practice and less well performing schemes. Emphasis shall be the importance of performance assessment and benchmarking as a basic management tool, it provides understanding of current performance ("where we are now") with identification of desirable and achievable performance ("where we want to be") and, through gap analysis, with actions required to achieve these desired levels of performance ("how we plan to get there"). Every project management shall consider the following points for sustainability of irrigation mamgement.

1. Water Management under Scarce Conditions.

The valuable management practices of each project during scarce water conditions need to be recorded. Lessons can be learnt from such experiences for dealing water scarce situations. The state of Andhra Pradesh has managed scarce water situations in Godavari and Krishna delta successfully and also improved productivity. Rotational irrigation and reuses of drainage water were some of the initiatives.

2. Large Scale Implementation of Water Saving Technologies

Any measures made towards promotion/execution of methods towards improvement of land and water productivity need to be mapped and accounted. In Krishna Delta presently more than 1 lakh acre area is put under direct seeded rice cultivation annually. Showing is done at the onset of monsoon and once canal water comes it is converted to wet cultivation. It is saving cost of cultivation of about Rs 5000 /- per acre apart from early harvest etc.

\section{Promotion of Micro Irrigation (MI) in large scale}

National task force committee on MI identified 69 million ha areas is suitable for micro irrigation in India. Now time has come to expand micro irrigation into command areas to improve water use efficiency substantially and increase productivity.

\section{Incentivizing Water Saving}

Concepts like virtual water and water credits are to be introduced to create awareness on saving of water and encourage the farmers or agencies for contribution towards improved water use efficiency through some incentives.

\section{Gross Productivity}

Accurate estimation of productivity achieved in each irrigation project is to be recorded accurately and also to be analyzed in terms of economic parameters. The economic value of the crop yields need to be worked out. Comparison with other projects will help in understanding the contribution made.

\section{Multiple Uses of Water and Economic Value}

Irrigation projects are serving important sectors apart from irrigation. It needs to accurately mapped and estimated the water utilized in various sectors and their economic contribution for economy. FAO has developed a tool called MASSMUS Application for evaluating Multiple Uses of Irrigation Projects.

\section{REFERENCES}

[1] Amarasinghe, U.A., Shah T., Turral, H. and Anand, B.K. 2007. India's water future to

a. 2025-2050: Business-as-usual scenario and deviations. Research Report 123,

[2] Burton, M.A., Rahul Sen, Simon Gordon-Walker, Anand Jalakam, and Arunabha Ghosh

a. (2011) National Water Resources Framework Study: Research Report Submitted to the Planning Commission for the 12th Five Year Plan, September, New Delhi: Council on Energy, Environment and Water and 2030 Water Resources 
Group, pp. i-584. http://ceew.in/pdf/CEEWWRG12Sep11.pdf

[3] Burton M A and A S Dhingra. Support for the Implementation of the National Water Mission

a. by State Governments in India: Scoping Study for a National Water Use Efficiency Improvement Support Program (Draft Report). Project Number: SC 100903 IND August 2013

[4] CWC. 2010. Summary report on water use efficiency (WUE) studies for 30 irrigation projects.

a. Performance Overview and Management Improvement Organisation (POMIO), Central Water Commission, Government of India, New Delhi, January.

[5] Dhingra A.S. \& Sen Rahul (2012). Sector Study on Development of Synthesis and Draft

a. Action Plan for Improving water Use efficiency of irrigated Agriculture in Selected Indian States. Asian Development Bank Project no. RSC C13535(IND) and RSC C-13696 (IND)

[6] FAO, 2008. Modernization strategy for irrigation management in Almatti Systems - KJBNL,

a. Karnataka, India. Food and Agriculture Organisation of the United Nations, Rome, June.

[7] GOI. 2012. National Water Policy, Government of India, New Delhi

[8] Malano, Hector and Burton, Martin (2001). Guidelines for benchmarking performance in the

a. irrigation and drainage sector. IPTRID Secretariat, Food and Agriculture Organisation of the UN, Rome.

[9] Murray-Rust, D.H. and Snellen, W.B. 1993. Irrigation system performance assessment and

a. diagnosis. Joint IIMI/ILRI/IHEE Publication, International Irrigation Management Institute, Colombo, Sri Lanka

[10] NWM. 2011. Comprehensive Mission Document, National Water Mission under National

a. Action Plan for Climate change, Government of India, New Delhi, April

[11]NWUEISP. 2013. Note on measures to improve water use efficiency and categorization of

a. MMI schemes, Scoping Study for a National Water Use Efficiency

[12] Verma, Shilip and Sanjiv J. Phansalkar. 2007. India's water future 2050: Potential

a. deviations from "Business as Usual". International Journal of Rural Management, 3(1), pp. 149179, Sage Publications, Los Angeles/London/New Delhi/Singapore. 